\title{
A Study on the Settlement Mechanism of Economic Law Dispute by Lawsuit JiaMing Pan
}

\author{
Tianjin University, Tianjin, 300072, China
}

Key words: economic law; dispute; lawsuit

Abstract: Economic prosperity can't only lay the material foundation for social progress, but also produce more and more economic disputes. In general, there are four solutions to economic disputes, namely, negotiation, arbitration, administrative settlement and lawsuit settlement. A fair and effective solution to economic disputes should also be a lawsuit solution. This paper firstly introduces the concept of economic disputes, elaborates the inevitability of lawsuit settlement of economic disputes, and discusses the establishment of dispute settlement mechanism according to the characteristics of China's economic disputes.

\section{Introduction}

China's economic law is an independent and emerging legal department. The emergence of economic law is the inevitable result of the state intervention in the market economy. It is the inevitable outcome of the development of commodity economy. Economic law takes the social interests as the starting point, dealing with and coordinates the state organs , social organization and the relationship between individuals; economic law is to regulate the economy for the purpose of the law, adjust the economic relations; economic law to take the means of diversity, which is a comprehensive adjustment of the law. Only by solving the economic law disputes can we make the economic law better serve the social economy and create a harmonious and stable social and economic environment. So that it can maintain the overall benefits of the social economy and rationally allocate social resources and coordinate the economic interests of all parties, and ensure the fair competition in the socialist market and promote the healthy and sustainable development of our socialist economy. From the position of the topic in the whole economic law, it is a relatively specific problem, the study of the problem, its significance mainly in the following aspects:

(1) which is an integral part of economic law theory. The law is to adjust the social relations, the law of life lies in the implementation. The ultimate goal of economic law research is to serve the practice of economic law to adjust the relationship between national economic regulation. Therefore, the theory of economic law is an organic part of economic law theory. In the rule of law society, justice is an indispensable way of law enforcement The In other words, the study of lawsuit resolution mechanism of economic law dispute is an indispensable part of economic law research ${ }^{[1-2]}$.

(2) this is the economic law function to play the needs. Economic law must be implemented to play its function, and justice is one of the important ways of its implementation, the lack of lawsuit protection of the implementation of economic law, it is difficult to play restricting the state administrative power to protect the role of national economic regulation. And because of the special nature of the economic law dispute itself, to solve the economic law dispute "close to the lawsuit" issue, it's obvious that a simple provision can't be a kind of disputes submitted to the lawsuit solution which can solve the problem, but also need to build from the theoretical basis to the system to do a comprehensive, systematic research.

In China, the state has long been the administrative order of the management of the economy, in the economic management of the disputes also to administrative order to solve the neglect of justice in the economic law dispute resolution role, the academic community is also a lack of lawsuit resolution of economic law specialized research. This situation in the socialist market economy is under the conditions of its obvious disadvantages. And "the revocation of the economic tribunal" is focused on the economic law dispute resolution mechanism of the plaque and urgency ${ }^{[3]}$. 


\section{The necessity of lawsuit solution to economic disputes and economic law disputes 2.1 The meaning of the dispute}

The so-called dispute, refers to the dispute no matter what. Disputes are the product of human life, because the dispute always takes place between two or more people, the island of Robinson, no one with the dispute. The cause of the dispute, first of all it is because of the nature of selfishness. Everyone is the pursuit of their own utility to maximize, however, the resources are always scarce, the wealth is always limited, a person's own pursuit of their own utility will inevitably damage to the utility of others to maximize the pursuit. Marx points out that everything that people strive for is related to their interests. In the final analysis, the dispute is the root cause of the dispute. Followed by individual differences. Due to people's knowledge, ability, rationality of the limited and differences, the same business or problems, often have different understanding. When the disagreement of the people adhere to their own views, the dispute will inevitably arise. Finally, because people understand the affairs of the position of the problem, the starting point of the difference. People know the affairs of the problem consciously unconsciously by their own position, the impact of the environment. The so-called "butt head" is a description of this phenomenon. In short, as long as there is a relationship between people, disputes are inevitable with the human interaction between each other increasingly frequent and extensive, the dispute will become increasingly complex and extensive. Disputes can be divided into private disputes, disputes between private and state, disputes between state institutions, and so on, depending on the subject of the dispute ${ }^{[4-5]}$. Figure 1 is an example of economic disputes, in which the lawsuit in which played a mediator role.

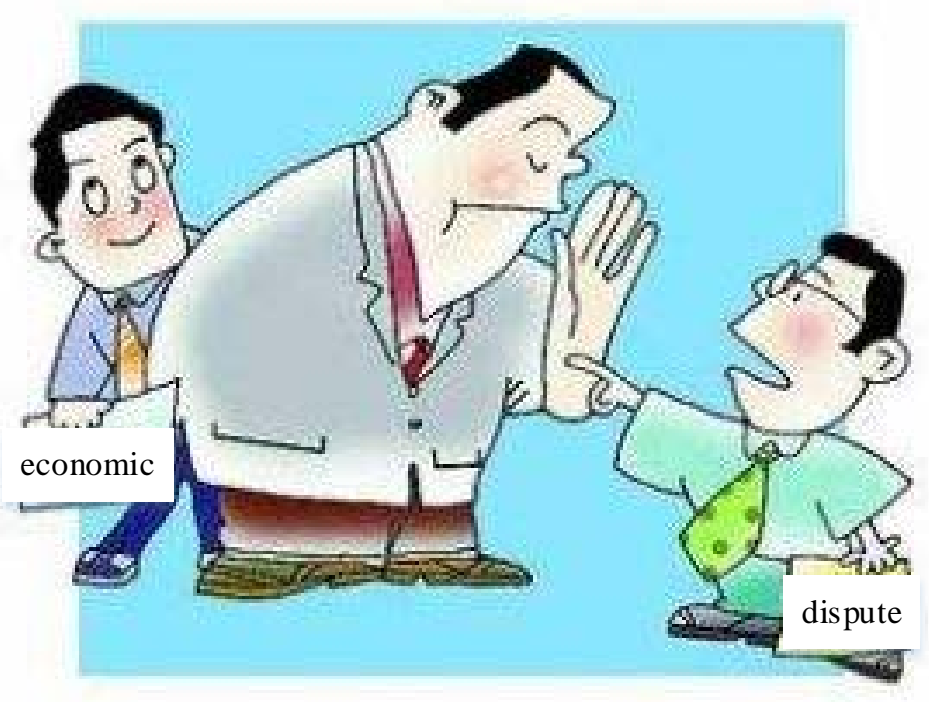

Fig.1 Economic disputes

\subsection{The meaning of dispute resolution}

Disputes are often considered to be the opposite of order, and disputes are always dissatisfied by one or both of the existing order and attempting to break it. We can't judge the value of good or evil for abstract disputes. There are absolutely evil disputes, such as "black eat black" battle with good and evil confrontation disputes, such as oppression of oppression also has no so-called Bodhisattva disputes, such as marriage disputes. Therefore, it is wrong to think that the dispute is evil, and thus fear the dispute, to avoid the dispute is wrong, especially in their own rights and interests are violated, to give up the power of the way to avoid disputes, it is not to. The significance of the dispute in order is that it is both the destructive power of the order and the influencing factors of the order to be restored and established. Some old, improper order, need to challenge it through the dispute, break it. If there is no dispute, unreasonable order will always exist, in this sense, the dispute is the power of human progress. Of course, this is only appearance, hidden behind the dispute, the dispute is the interests of the dispute, so that the pursuit of the interests of human progress is the real strength ${ }^{[6-7]}$. 
No matter what the dispute, to be resolved, but also will be resolved in some way, but, some way completely eliminate bait disputes, and some way is only temporarily suppressed the dispute. While in the pressure of disputes and brewing a greater dispute, the settlement of the dispute, either the return to the previous order, or the establishment of a new order. Whether it is to return to the old order, or to establish a new order, are of great significance. To return to the old order, it strengthens the order of binding, maintaining the order, if the order of any violation can't be stopped, then the order will cease to exist, human society will inevitably fall into chaos. In order to establish a new order, the continuous emergence of new disputes and the formation of a new order in resolving new disputes is a manifestation of order evolution. Without the establishment of a new order in dispute settlement, there is no order to move forward. It has also been pointed out that the handling of disputes and the gradual and steady change of order under the premise of maintaining certain stability and continuity "disputes and disputes are treated as such a way of being able to interact through countless microscopic individual interactions flow and reflection into the norms, order to go, so as to promote the order of the internal gradually, but may also be a fundamental change in the device.

\subsection{The necessity of lawsuit solution to economic law dispute}

In the process of national economic regulation, the economic adjustment of the economic rights and economic obligations arising from the reorganization or redistribution of the social resources by the state economic adjustment subject is the economic law dispute. Due to the scarcity of resources, limited, the national economic adjustment of the main body in any case of social resources and social wealth, will break the allocation or distribution of the existing balance, while some people benefit at the same time, but also damage the interests of another part of the people. The interests of the injured party in order to maximize the avoidance of losses, which led to the interests of the interests of the main dispute; In addition, the national economic adjustment in the adjustment of economic activities, once the abuse of economic adjustment, will lead to national interests, public interest Damage will lead to the emergence of economic law disputes; different economic law between the main interests of the conflict will lead to the emergence of economic law disputes. Economic law disputes, if there is no effective solution, will directly affect the economic law compliance and implementation, can't create a balanced and harmonious socio-economic environment, can't be a reasonable allocation of resources, is not conducive to sustainable development of social economy ${ }^{[8]}$.

In theory, economic law has a litigation, that is, economic law disputes can be resolved through lawsuit channels, that is, economic law disputes. People can appeal to the court to seek a solution. Economic disputes are different from civil disputes, administrative disputes and criminal cases, the lawsuit settlement mechanism of these disputes does not apply to economic law disputes, China's economic law disputes are mostly used as administrative solutions to the final solution, there is no appeal to the court. It is possible to effectively supervise and restrict the exercise of the power of the state administrative organs, that is, to restrict the economic adjustment of the state organs of power, and to ensure that the economic power of the state organs of power can be effectively monitored and constrained by the lawsuit power of the state organs, thus avoiding the chaos of economic regulation, to prevent the breeding of corruption.

\section{Economic law dispute case settlement mechanism}

\subsection{Civil litigation to resolve economic law disputes}

The civil litigation system is a dispute involving the interests of the equal main body. When the dispute of economic law occurs between the equal subjects, it can be solved through civil lawsuit affairs, including ordinary civil lawsuit litigation system and special civil litigation system. However, the main body of economic law disputes between the status and capacity is unequal, which requires the existing civil justice system to reform the system, you can use the burden of proof of the inverted measures, or the parties in a weak position and the parties to provide legal aid as shown in figure 2, as well as to simplify the proceedings and other measures to correct the status of inequality between the parties to the status quo; also by reducing the cost of litigation, the implementation of group litigation system, the establishment of small litigation system, the implementation of electronic services, 
improve the publicity system and other measures, To correct the impartiality and efficiency of lawsuit settlement; to increase the impartiality of the proceedings and to ensure the impartiality of justice. The special civil litigation system to solve the dispute of economic law includes civil litigation system, including group civil litigation system and public welfare civil litigation system.

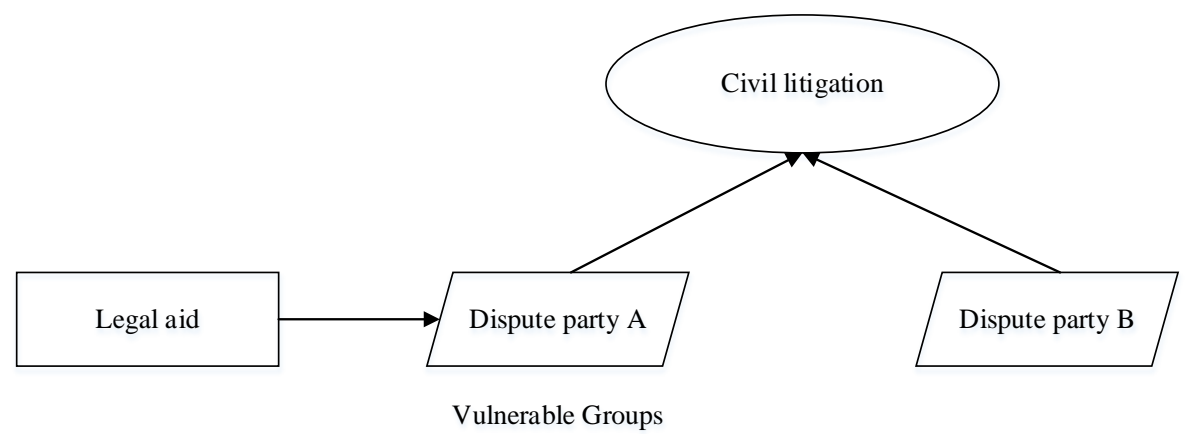

Fig.2 Examples of civil action settlement of disputes

\subsection{Administrative litigation to resolve economic law disputes}

Administrative litigation(in figure 3) is an organization or individual that involves the exercise of administrative rights by state administrative organs or laws and regulations, and is often targeted for specific administrative acts, including general administrative litigation system and special administrative litigation system. The state regulates the economy by the state or the administrative organs authorized by the administrative organs to exercise the economic adjustment, the national economic adjustment between the main body, the adjustment between the main body and the national economic adjustment between the main third party and the national economic adjustment of the main body The economic law disputes involving the main body of the national economic regulation can be resolved through administrative litigation. The general administrative litigation system has expanded the scope of the case acceptance, established the group administrative litigation system, and made the amendment to the administrative litigation type, the evidence collection and the burden of proof, the withdrawal and the regulation, so as to meet the need of lawsuit resolution of economic law dispute. Special administrative litigation system includes public interest administrative litigation system, administrative law enforcement litigation system and organ litigation system.

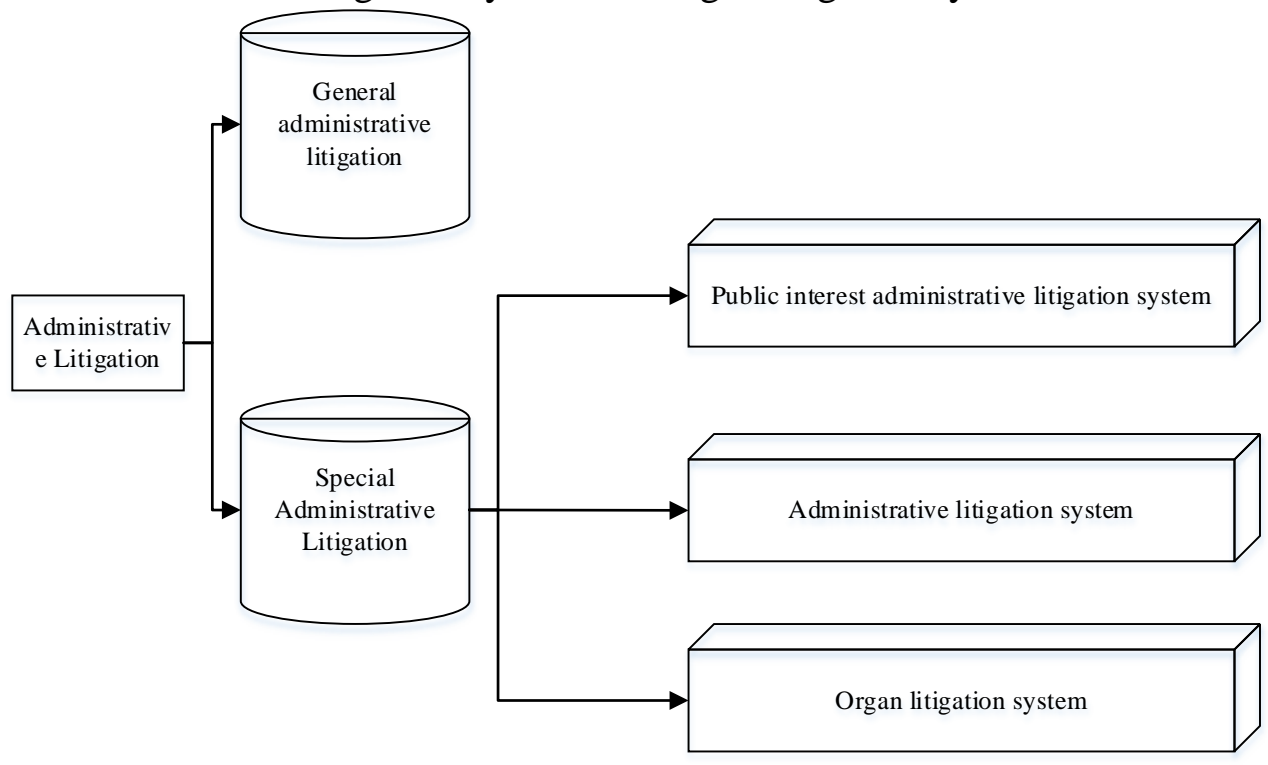

Fig.3 Administrative Litigation 


\section{Summary}

Through this research, economic law disputes can generally be resolved in ordinary civil litigation and general administrative litigation, but when the ordinary civil litigation and general administrative litigation are difficult to solve or solve the high cost of economic law disputes. You can establish a special civil litigation system and special administrative litigation system to be effectively resolved. We should establish a model of ordinary civil litigation, special civil litigation, general administrative litigation and special administrative litigation. It is of great significance to perfect the law of our country by paying attention to the construction of lawsuit resolution mechanism of economic law disputes with Chinese characteristics.

\section{References}

[1] Boyd C L, Hoffman D A. Litigating toward settlement [J]. Journal of Law, Economics, and Organization, 2013, 29(4): 898-929.

[2] Tallberg J, McCall Smith J. Dispute settlement in world politics: States, supranational prosecutors, and compliance [J]. European Journal of International Relations, 2014, 20(1): 118-144.

[3] Simmons B A. Bargaining over BITs, arbitrating awards: The regime for protection and promotion of international investment [J]. World Politics, 2014, 66(01): 12-46.

[4] Prescott J J, Spier K E, Yoon A. Trial and Settlement: A Study of High-Low Agreements [J]. The Journal of Law and Economics, 2014, 57(3): 699-746.

[5] Fooks G, Gilmore A B. International trade law, plain packaging and tobacco industry political activity: the Trans-Pacific Partnership [J]. Tobacco control, 2014, 23(1): e1-e1.

[6] Büthe T, Milner H V. Foreign direct investment and institutional diversity in trade agreements: Credibility, commitment, and economic flows in the developing world, 1971-2007[J]. World Politics, 2014, 66(01): 88-122.

[7] Elsig M, Pollack M A. Agents, trustees, and international courts: The politics of lawsuit appointment at the World Trade Organization [J]. European Journal of International Relations, 2014, 20(2): 391-415.

[8] Thow A M, Snowdon W, Labonté R, et al. Will the next generation of preferential trade and investment agreements undermine prevention of non-communicable diseases? A prospective policy analysis of the Trans Pacific Partnership Agreement [J]. Health Policy, 2015, 119(1): 88-96. 